\title{
War and the Survival of the Fittest-I*
}

\author{
Does Physical Conflict Between the Nations Select the Highest Type?
}

By Robert M. Dickie

Evolutionists who are accustomed to magnify the office of natural selection as a key to every problem, look upon war as the final expression of a law wrought into all life. They point out that during the long history of life from its earliest dawn upon our planet there tory of life from its earliest dawn upon our planet there and less fit have gone to the wall and the superior type has survived and perpetuated itself. "Nature red in tooth and claw" has "with ravine shrieked" from the beginning. But, despite all this apparently immeasurable waste and cruelty, there has been through this process a gradual improvement of the types of life. The unfit have gone to the wall and left no descent, whereas the fit have survived and brought forth after their kind. The struggle for existence, turning nature into a shamble as it has, bas yet been the mother of progress. In this prodigality of cruelty and death there is to be traced the history of life mounting to ever higher forms. Natural selection, we are assured, has been wrought into life
from the beginning and is the sacred instrument of progress.

All life, we are assured, is of a piece and within the grip of this all-embracing law. It is true of human life as of lower orders. When we come to the history of man we find such a struggle in the first dawn of savage life in which the stronger and more resolute and crafty survive. We have but mounted higher in the order of life, we have not escaped its law and the condition of its progress. As it is with individuals so it is with communities of life. This natural warfare is arrested among certain individuals in the interest of their common social life. But presently instead of individuals, we have communities, families, tribes, races, at war. Here also conflict is the condition of progress. Those primitive societies in which the "social tissue" or solidarity of life was most highly developed, vanquished their fellows and either exterminated them or made them their hewer of wood and drawers of water as best served their purpose. These early tribal wars were thus a process of
selection in which the weaker and less fit were eliminated and the strongest survived.

Nations and empires are simply larger communities of life subject to the same law. They must struggle one with the other, and out of that struggle come one with the other, and out of that struggle comes "Storm purifies the air and destroys frail trees, leaving the sturdy oaks standing. War is the test of a nation's political, physical and intellectual worth. The stat in which there is much that is rotten may vegetate for a while in peace, but in war its weakness is revealed." (Prof. Baron Karl von Stengel in "Weltstaat un reieden " that govern all life-plant, animal or national, the law that govern all life-plant, animal or national, the law
of struggle, the law of survival. These laws so universal of struggle, the law of survival. These laws so universal as regards life and time, so unalterable in causation and national existence as the knowledge of them and obedience to them is proportionately true or false. Plan to thwart them, to shortcut them, to circumvent, . to cozen, to deny, to scorn and violate them is folly such as man's conceit alone makes possible. Never has thi been tried, and man is ever at it. but that the end has been gangrenous and fatal." (Gen. Homer Lea in "Th Valor of Ignorance"). The argument from biology i Valor of Ignorance"). The argument from biology is
thus twofold; war is the inexorable law of life which thus twofold; war is the inexorable law of life which
only stupidity will challenge and the sacred instrument of life's evolution which we all must revere.

But the terms "struggle for existence," "natural selection" and "survival of the fittest" lend themselves, in popular speech, to loose and indefinite use. It is easy to read "struggle for existence" as mortal combat between the different forms of life through all their ascending orders. Thus, we picture the early history of lif as a warfare in which every individual had to fight every other individual that happened the same way and in which the strongest survived. But this is to misread the term as used in biological theory, and to this misreading. much of the plausibility of the abov argument is due.

The struggle for existence is indeed the law of all life. To live means to maintain a certain correspondence with nature. Life continues only so long as such an adaptation is maintained. This necessity laid upon an organism to maintain a correspondence with nature in order to live makes all life a struggle for existence. it is also the mother of invention and the mainspring of progress, for perfection of life is measured by the * Reproduced from Queen's Quarterly. perfection of the organism's adaptation to its environ-
ment. But this struggle for existence is essentially a struggle of the organism with its environment, and goes on even where organisms of like kind live at peace with one another. Struggle between individual organisms is not necessary to natural selection, at most it is only ncidental to it.

The environment with which an organism must struggle in order to adapt itself may, and usually does, include other like organisms as well as natural forces. The argument of the militarist drawn from biological theory assumes that the struggle for existence is essentially a struggle of one form of life with another, whereas it really is, in its esereas environment. It further assumes that the organism must struggle and contend with such other organisms as belong to its environment. But this assumption is neither true to fact nor essential to biological theory. Not all forces either inorganic or organic in the organism's environment must be contended against in order to live. The lizard does not contend with the warm sun which freely shines upon it and contributes to its vital force, though it has to protect itself as best it can against the frost. The frost is his natural enemy and he has to contend against it, but the warm sun is his friend, he must welcome it. With respect to the inorganic elements of an organism's environment, it is altogether misleading to speak of their having to be contended with in order to live. Some elements are inimical to life and health and others are conducive to them. Against the former the organism struggles and resists as best it can; with the latter it co-operates. In relation, then, to the natural forces to which life must adapt itself, struggle, in the sense of contending against, expresses only one side of the organism's attitude toward its environment, and that the negative or defensive side; the other and positive side and that from which alone progress may be expected is to be expressed by the term co-operation.

Nor is it otherwise in the case of the organic part of an organism's environment. If a life had to contend it every other life that came within its environment it is as difficult to see how any life could survive as it would be if every inorganic force which touched a life
were inimical to it. If that were the rule, parents were inimical to it. If that were the rule, parents
would devour their offspring and there would be nothing to survive. But this is not the rule of nature; and not only so, but it is not the rule among the orders of lower life which come under our observation that a life lives at war with other lives of its kind within its environment. "Dog does not eat dog" and tiger does not hunt tiger. Such conflicts as do occur, usually ove mating and food, may be described as incidental but not necessary to life. In the case of animals that mate not necessary to life. In the case of animals that mate
in pairs there may be a conflict between males, but in such cases the weaker is not usually killed but simply forced to choose another mate. In the case of conflic over food the result is usually to scatter the contending parties over a wider area of territory, that is, to remove the one out of the environment of the other, and what one gains in ferocity and insolence the other gains in craftiness. I am not here concerned with lives of a different species which come within an organism's environment and are a menace to its life, for the theory of natural selection is primarily concerned with the struggle for existence among individuals of one kind or species, and the point to be insisted upon is that among the lower orders of life war is not the necessary and universal rule. An organism does not come into the world fighting, spend its brief span fighting and die fighting its own kind which come within its environment.

There is another feature in the relation of an organism to other organisms of its kind in its environment which appears comparatively early in the history of ascending life and which is of the utmost importance in the light of social organization. The relation of the organism to positive and favorable forces of nature in its environment we have described as co-operation. Very early in the history of life there appears another and highe manner of co-operation, the co-operation between an organism and similar organisms in its environment. The struggle of an organism to adapt itself to the conditions of existence is of the essence of all life. The system of natural forces among which it lives is absolutely impassive so far as the life which lives upon them is impassive so far as the life which lives upon them is
concerned. But when similar organisms possessed of similar capacities for adaptation become a part of life's environment we have'entered upon a new phase of lif and become aware of a new form of co-operation, no now the co-operation of a vital life-conserving energy inorganic nature, but the co-operation of life with life. Now it becomes possible for the environment of the individual life positively and purposely to minister to the maintenance and enrichment of its life. Life-conserving purpose is both in the organism and its environment. This is to be seen in the attitude of very primi tive types of life toward their offspring. The jealous care and protection given by the tigress to her cubs and the solicitude of the eagle in teaching her young to fly remind us that even in the fiercest types of life there is more than heartless ferocity and selfishness. Under the guidance of sex instinct lower orders of life co-operate in the struggle for existence both for their own mutual advantage and that of their offspring. Male and female in the early types of life have been helpers the one of the other in their struggle against common enemies,
Here we have the beginnings of community life, the promise and potency of all social life. The extent to which such co-operation of organism with organism in a community life may be carried among the lower orders of life is to be seen, for instance, in an ant-hill or a bee-

Then the argument from biology which says that the warfare of life with life is a universal law bolding all life within its grip is not true to fact. Life is everywhere at war only with the forces in its environmen which are inimical to it. When other organisms come within an individual's environment they are sometimes its enemies but sometimes its friends. Co-operation of life with life is as much a fact as the struggle of life with life and becomes increasingly common as we mount up in the scale of life. The other argument we mount up in the scale of life. The other argument
which says that this struggle for existence is the instrument by which progress in type of life is achieved confuses the struggle of life with nature with that of life with life. In the essential struggle for existence it is not the stronger type which pushes the weaker to the wall, but nature itself with which they fail to make a satisfactory adjustment. The process by which the and perperive struggle of life with life is not essential to it; at most it is only incidental.

( $T$ o be continued)

Use of Mirror in ${ }_{\bar{\pi}}^{\mathbf{*}}$ Watching Stack Smoke

Sт. L॰UIs has a strict smoke-prevention ordinance, and the fireman who shovels coal carelessly, with consequent clouds of black smut from the stack, is likely soon to find the firing aisle blocked by a couple of bluecoats with shining nickel-plated stars. The ordinance has be assistance to the Union Electric plants to its care, where they receive scientific intelligent supervision. For instructing its firemen in proper coaling and methods at the old Imperial district-heating plant, Tenth and St. Charles Streets, a 36-inch by 36-inch plate-glass mirror has been mounted on a framework in the yard outside the boiler room, so that the top of the smokestack can be seen from any point in front of the boilers. Rigelmann's charts of smoke density are posted conveniently near, and the fireman can take observations from time to time without leaving his station.-Electrical World.

\section{Artificial Ebony from Oak Wood}

Consul William H. Hunt, St. Etienne, France, describes the following as a good process for converting are immersed for 4 hours in a warm saturated solution of alum and sprinkled several times with a decoction of logwood; smaller pieces may also be steeped for a certain length of time in the decoction, which is prepared in the following manner: One part of logwood of best quality is boiled with 10 parts of water; it is then filtered through linen and the liquid evaporated at low temperature until its volume is reduced by one half, and to every quart of this bath are added 10 to 15 drops of a saturated solution of soluble indigo entirely neutral in reaction. After having watered the blocks several times with this solution, the wood is rubbed with a saturated and filtered solution of verdigris in warm concentrated acetic acid, and this operation re peated until a dark color of the desired intensity is obtained. The oak wood dyed after this fashion presents an aspect similar to that of real ebony. 